\title{
Expression and role of estrogen receptor $\alpha$ and $\beta$ in medullary thyroid carcinoma: different roles in cancer growth and apoptosis
}

\author{
Mi Ae Cho' ${ }^{1,2,3}$, Mi Kyung Lee ${ }^{4}$, Kee-Hyun Nam ${ }^{2,3,5}$, Woung Youn Chung ${ }^{2,3,5}$, Cheong Soo Park ${ }^{2,3,5}$, \\ Ju Hyeong Lee ${ }^{1,2,3}$, Taewoong Noh ${ }^{1,2,3}$, Woo Ick Yang ${ }^{6}$, Yumie Rhee ${ }^{1,2,3}$, Sung-Kil Lim ${ }^{1,2,3}$, \\ Hyun Chul Lee ${ }^{1,2,3}$ and Eun Jig Lee ${ }^{1,2,3,7,8}$ \\ ${ }^{1}$ Division of Endocrinology, ${ }^{2}$ Thyroid Cancer Clinic and ${ }^{3}$ Research Institute of Endocrinology, Yonsei University College of Medicine, Seoul, South Korea \\ ${ }^{4}$ Department of Pathology, National Health Insurance Corporation, Ilsan Hospital, Koyang, South Korea \\ ${ }^{5}$ Department of Surgery, ${ }^{6}$ Department of Pathology and ${ }^{7}$ Center for Chronic Metabolic Disease Research, Yonsei University College of Medicine, Seoul, \\ South Korea \\ ${ }^{8}$ Endocrinology, Metabolism, and Molecular Medicine, Feinberg School of Medicine, Northwestern University, Chicago, Illinois 60611, USA \\ (Correspondence should be addressed to E J Lee at Division of Endocrinology, Yonsei University College of Medicine, 262 Seongsanno Seodaemungu, \\ Seoul 120-752, South Korea; Email: ejlee423@yuhs.ac)
}

\begin{abstract}
Medullary thyroid carcinoma (MTC) originates from parafollicular C cells. Estrogen receptor $\beta$ (ER $\beta)$ expression was detected in normal parafollicular C cells and MTC tumor tissue, but ER $\alpha$ expression in MTC tumors still remains undetermined. The appearance and loss of ER $\alpha$ or ER $\beta$ expression has been known to play a role in the development and progression of many human cancers. We performed immunohistochemical studies of $\mathrm{ER} \alpha, \mathrm{ER} \beta$, and Ki67, a mitotic index, in 11 human MTC tissue samples. ER $\alpha$ was detected in 10 cases (91\%), and $\operatorname{ER} \beta$ expression was observed in 8 cases $(72 \cdot 7 \%)$. A majority $(8 / 10)$ of ER $\alpha$-positive tumors showing ER $\beta$ Ki67 expression was detected in three cases $(27 \cdot 3 \%)$. Neither clinical parameters nor tumor node metastasis (TNM) tumor staging was correlated with the positivity for ERs or Ki67. To investigate the biological role of each ER, we used ER-negative MTC TT cells and adenoviral vectors carrying $\operatorname{ER} \alpha(\operatorname{Ad}-\mathrm{ER} \alpha), \operatorname{ER} \beta(\operatorname{Ad}-\mathrm{ER} \beta)$,
\end{abstract}

estrogen response element (ERE)-Luc (Ad-ERE-Luc), and activator protein 1 (AP1)-Luc (Ad-AP1-Luc). Estrogen stimulated and anti-estrogen, ICI 182 780, suppressed ERE reporter activity in TT cells expressing ER $\alpha$ or ER $\beta$, suggesting that both ERs use the same classical ERE-mediated pathway. Ad-ER $\alpha$ infection stimulated TT cell growth; in contrast, Ad-ER $\beta$ infection suppressed their growth. Apoptosis was detected in Ad-ER $\beta$-infected TT cells. Estrogen and antiestrogen suppressed AP1 activity in Ad-ER $\alpha$-infected cells, whereas upon Ad-ER $\beta$ infection estrogen further stimulated AP1 activity which in turn is suppressed by anti-estrogen, suggesting that each ER acts differently through a non-EREmediated pathway. Our results suggest that $\operatorname{ER} \alpha$ and $\operatorname{ER} \beta$ may play different roles in MTC tumor growth and progression.

Journal of Endocrinology (2007) 195, 255-263

\section{Introduction}

Medullary thyroid carcinoma (MTC), which comprises 3-10\% of all carcinomas in the thyroid gland, may be either sporadic or familial. Sex ratio is $1: 1$ with no difference between sporadic and familial MTC (Kebebew et al. 2000a,b). The familial form is part of the multiple endocrine neoplasia type 2 (MENII) syndrome. MTC arises from the parafollicular $\mathrm{C}$ cells of the thyroid gland. Metastases to distant sites including lungs, liver, and bone usually occur early. Therefore, any form of effective therapy with curative intent must be systemic (Messina et al. 2000). The primary form of treatment for MTC is total thyroidectomy, but recurrent and metastatic diseases are difficult to manage. Although many patients live with a recurrent or residual tumor for up to a decade, the case fatality rate is ultimately $30-50 \%$ over 10 years (Marsh et al. 1995). Because MTC responds poorly to both chemotherapy and radiotherapy, targeted therapy through cancer-specific signaling may offer an alternative approach (Petrangolini et al. 2006).

Parafollicular C cells secrete a polypeptide hormone, calcitonin. Previously, it has been demonstrated that calcitonin gene expression is elevated in response to estrogen, suggesting the presence of an estrogen receptor (ER; Naveh-Many et al. 1992). Immunohistochemical studies using monoclonal antibody revealed that $\mathrm{ER} \beta$, but not $\mathrm{ER} \alpha$, was detected in normal human thyroid follicular and parafollicular $\mathrm{C}$ cells (Taylor \& Al-Azzawi 2000). More recently, a study showed that ER $\beta$ was expressed in most of the MTC tissues (Blechet et al. 2007). However, immunohistochemistry results (Bur et al. 1993, Hiasa et al. 1993, Yane et al. 1993, Colomer et al. 1996, Lewy-Trenda 2002, Arain et al. 2003, Blechet et al. 2007) 
demonstrating ER $\alpha$ expression in thyroid tumors including follicular adenoma or carcinoma, papillary carcinoma, medullary carcinoma, and anaplastic carcinoma remain controversial depending on the antibody source.

Thyroid cancer is more prevalent in women than men, and thyroid cancer incidence decreases after menopause (Cady et al. 1979). These facts suggest a possible involvement of estrogens in the carcinogenesis and progression of thyroid cancer. Demonstration of ER $\alpha$ protein (Lee et al. 1998) and ER $\alpha$ mRNA (Yane et al. 1994) in the normal and malignant tissues of the thyroid seems to further support the hypothesis that there is a direct action of estrogens on the thyroid tissues and tumors. Estrogen has long been known to promote the growth of certain human neoplasms, notably tumors of the breast, endometrium, and pituitary. In contrast, ER $\beta$ appears to play a different role in carcinogenesis. Many reports have shown that a loss of ER $\beta$ expression is associated with the progression of normal prostate epithelium into prostate cancers (Latil et al. 2001, Leav et al. 2001, Fixemer et al. 2003). A similar down-regulation in ER $\beta$ expression is also noted in ovarian, breast, or colon tumors (Pujol et al. 1998, Roger et al. 2001).

The expression of ERs or their biological role in the MTC remains unclear. In this study, we investigated the ERs expression in human MTC tissues and examined the role of ERs using ER-negative MTC TT cells after expression of ERs by adenoviral vectors.

\section{Materials and Methods}

\section{Subjects and immunohistochemistry of human MTC tumor}

Eleven patients (five men and six women, mean age 48 years) with MTC were included in this study. Ten patients had sporadic MTC and one had MENIIa presenting as bilateral MTC. The diagnosis of an MTC was established by the measurement of serum calcitonin and carcino embryonic antigen (CEA), and confirmed in all cases by positive immunohistochemical staining of tumor tissue for calcitonin (10 cases), CEA (11 cases), or chromogranin-A (10 cases). One patient (case 5) with negative for calcitonin and chromogranin-A had elevated serum CEA and immunohistochemical positivity for CEA. Every MTC were poorly differentiated under light microscopic examination. Metastatic cervical lymph nodes were identified in seven patients $(63.6 \%)$ and distant metastasis occurred in two patients $(16 \cdot 6 \%)$. The study design and protocol was approved by the Internal Review Board of Severance Hospital, Yonsei University College of Medicine.

To detect ER $\alpha$ or ER $\beta$ in MTC tumors, $4 \mu \mathrm{m}$ sections of tumor in paraffin blocks were prepared. After deparaffinization, slides were placed in a jar containing $10 \mathrm{mM}$ sodium citrate buffer (pH 6.0), exposed to microwave radiation $(1000 \mathrm{~W})$ for $15 \mathrm{~min}$, and cooled to room temperature. After preincubation with serum blocking solution, slides were incubated with mouse monoclonal anti-human ER $\alpha$ (1:50, sc-8002, Santa Cruz Biotechnology Inc., Santa Cruz, CA, USA specific to C-terminal human ER $\alpha$ ) or ER $\beta$ (1:50, NCL-ER $\beta$, NovoCastra, specific to C-terminal human ER $\beta$ ) respectively, overnight in a cold room. After washing with Tris-buffered saline (TBS) $/ 0 \cdot 025 \%$ Tween, staining was performed by biotinylated horse anti-mouse secondary antibodies $(5 \mu \mathrm{g} / \mathrm{ml}$, Vector Laboratories, Burlingame, CA, USA), streptavidinhorseradish peroxidase (RTU, Vector), and diamino benzidine (DAB; DAKO). The concentration of each antibody was titrated using positive and negative control breast cancer tissues to minimize non-specific staining. Counterstaining was performed by malachite green. To investigate a possible correlation of the presence of ERs with a cell proliferative index, Ki67 immunohistochemistry was also performed by mouse monoclonal antibody (1:50, DAKO, Fort Collins, CO, USA). Images were obtained using a Zeiss microscope (Axioskop, Carl Zeiss Inc., Oberkochen, Germany).

\section{Recombinant adenoviral vectors}

Adenoviral vectors carrying the human $\operatorname{ER} \alpha(\operatorname{Ad}-E R \alpha)$ and ER $\beta$ (Ad-ER $\beta$ ) were described previously (Cheng et al. 2004). E1-deleted adenoviral vector (Ad-E) was used as a negative control. Adenoviral reporter vectors, Ad-3ERE-Luc and Ad-AP1-Luc, were created to investigate transcriptional activity of the ER $\alpha$ or ER $\beta$ delivered by adenoviral vectors. The sequence containing three consensus estrogen response elements (3 ERE) and minimal TATA promoter was generated by oligonucleotide annealing and ligated to the pGL3-basic plasmid (Promega). A portion of the resulting plasmid containing the upstream synthetic $\mathrm{p}(\mathrm{A})$ signal, 3 ERE, a minimal TATA promoter, the firefly luciferase gene, and the downstream SV40 p(A) signal was subcloned into an adenoviral transfer plasmid. The resulting plasmid, pC-3ERE-Luc, was used to generate Ad-3ERE-Luc. Similarly, Ad-AP1-Luc was generated from pC-AP1-Luc, in which the sequence containing seven AP1 sites was switched with three ERE sequences in pC-3ERE-Luc. The sequences of the expression cassettes in the adenoviral vectors were confirmed by automated DNA sequencing.

\section{Cell culture and infection with recombinant adenoviruses}

TT cells were obtained from the American Type Culture Collection (Rockville, MD, USA) and maintained in Dulbecco's modified Eagle's medium (DMEM) $/ \mathrm{F} 12+10 \%$ FBS supplemented with 100 units $/ \mathrm{ml}$ penicillin and $100 \mu \mathrm{g} / \mathrm{ml}$ streptomycin and were incubated at $37^{\circ} \mathrm{C}$ and $5 \% \mathrm{CO}_{2}$.

For infection with adenoviral vectors, cells were first depleted of estrogen for 3 days using phenol red-free DMEM/F12 containing 5\% dextran/charcoal-stripped FBS. Transduction efficiency of the adenoviral vectors in cell lines was tested using AdGal. $\beta$-galactosidase expression was detected in $95-100 \%$ of TT cells at $48 \mathrm{~h}$ after infection with AdGal at a multiplicity of infection (MOI) of 10 
plaque-forming units (PFU) per cell (data not shown). Therefore, subsequent experiments were performed by similar amounts (10 or $20 \mathrm{PFU} /$ cell) of recombinant adenoviral vectors.

The transcriptional activities of $\mathrm{ER} \alpha$ or $\operatorname{ER} \beta$ were assayed using an artificial estrogen-responsive reporter (Ad-3ERE-luc) or AP1 reporter (Ad-AP1-luc) in a viral vector (Lee et al. 2001). Briefly, 12-well plates of TT cells were infected for $5 \mathrm{~h}$ with $10 \mathrm{PFU} /$ cell Ad-3ERE-Luc or Ad-AP1-Luc with Ad-ER $\alpha$ or Ad-ER $\beta$. Fresh medium containing ethanol vehicle, 17 $\beta$-estradiol ( $\mathrm{E}_{2}, 1 \mathrm{nM}$, Sigma), or ICI 182780 (100 nM, Tocris, Ellisville, MO, USA), a specific estrogen antagonist, was added; incubation continued for $24 \mathrm{~h}$; and luciferase activity was assayed.

\section{Detection of ERs expression using immunofluorescence and western blot analysis}

TT cells on glass slides $48 \mathrm{~h}$ after infection with adenoviral vectors were fixed in ice-cold methanol for $10 \mathrm{~min}$ and permeabilized with $0 \cdot 4 \%$ Triton-X 100 in PBS for $20 \mathrm{~min}$ on ice. After blocking with 10\% horse serum for $30 \mathrm{~min}$, specimens were incubated with mouse monoclonal antihuman $\mathrm{ER} \alpha$ or $\mathrm{ER} \beta$ for $1 \mathrm{~h}$ at room temperature. After washing with TBS $+0 \cdot 025 \%$ Tween, specimens were incubated with biotinylated horse anti-mouse secondary antibodies (5 $\mu \mathrm{g} / \mathrm{ml}$, Vector Laboratories) for $30 \mathrm{~min}$. Streptavidinfluorescein isothiocyanate (FITC) (1:100, Vector) and Streptavidin-Texas-Red (1:100, Vector) were used for the detection of $\operatorname{ER} \alpha$ and $\operatorname{ER} \beta$ respectively. Cell images were analyzed using a Zeiss microscope (Axioskop, Carl Zeiss Inc).

Infected TT Cells in $10 \mathrm{~cm}$ culture dishes at a density of 5 $\times 10^{6}$ cells/dish were washed twice with PBS, and whole cell lysates were prepared with lysis buffer (25\% glycerol, $0.5 \mathrm{M}$ $\mathrm{NaCl}, 1.5 \mathrm{mM} \mathrm{MgCl} 2,20 \mathrm{mM}$ HEPES (pH 7.9), $1 \mathrm{mM}$ phenylmethylsulfonyl fluoride, 0.2 mM EDTA, $25 \mathrm{mM} \mathrm{NaF}$, and protease inhibitor cocktail tablets (Roche Molecular Biochemicals)). Equal amounts of protein $(10 \mu \mathrm{g})$ were resolved by SDS-PAGE on $10 \%$ gel and transferred to nitrocellulose paper. $\operatorname{ER} \alpha$ or $\operatorname{ER} \beta$ was detected using the antibodies as described above.

\section{The effect of ERs on TT cell growth}

The effect of ER $\alpha$ or ER $\beta$ on TT cell growth was measured with a non-radioactive cell proliferation assay according to the manufacturer's protocol (Cell Titer 96 Aqueous NonRadioactive Cell Proliferation Assay, Promega). Cells were seeded onto 96-well plates at a density of $8 \times 10^{3}$ cells/well and infected the following day with adenoviral vectors at different MOIs (10 and $20 \mathrm{PFU} /$ cell). Medium containing ethanol vehicle, $E_{2}(1 \mathrm{nM})$, or ICI 182780 (100 nM) was replaced at $5 \mathrm{~h}$ after infection and every two days thereafter. Octaplicate wells were assayed for viable cell density at day 8 . Relative density was calculated as absorbance at $490 \mathrm{~nm}$ divided by that of the Ad-E-infected, $0 \mathrm{nM} \mathrm{E}$-treated cells, and expressed as a percentage (mean \pm S.D).

\section{Terminal deoxynucleotidyltransferase (TdT)-mediated UTP end labeling (TUNEL) assay}

TT cells were infected with adenoviral vectors (10 PFU/cell), treated with $1 \mathrm{nM} \mathrm{E}_{2}$ for 6 days, and then washed twice with PBS and mounted on glass slides. Cells were fixed for $30 \mathrm{~min}$ in $4 \%$ paraformaldehyde and permeabilized with buffer containing $0 \cdot 1 \%$ sodium acetate and $0 \cdot 4 \%$ Triton X-100 for 10 min on ice. After washing with PBS, a modified TUNEL was performed by the In Situ Cell Death Detection Kit, Fluorescein (Boehringer Mannheim Co). TUNEL-positive

Table 1 Summary of clinical and pathologic characteristics of patients with medullary thyroid carcinoma

\begin{tabular}{|c|c|c|c|c|c|c|c|c|c|}
\hline & & & & & Plası & a level & & ohistochen & \\
\hline & Sex & TNM (staging) & $\begin{array}{l}\text { Duration of } \\
\text { follow-up } \\
\text { (years) }\end{array}$ & $\begin{array}{l}\text { Age at } \\
\text { diagnosis }\end{array}$ & $\begin{array}{l}\text { Calcitonin } \\
(\mathrm{pg} / \mathrm{ml})\end{array}$ & $\begin{array}{l}\text { CEA } \\
(\mathrm{ng} / \mathrm{ml})\end{array}$ & $\mathrm{ER} \alpha$ & $\mathrm{ER} \beta$ & Ki67 \\
\hline $\mathrm{Nu}$ & & & & & & & & & \\
\hline 1 & M & T2N1b M0(IVA) & $13(\mathrm{~A})$ & 32 & 320 & $27 \cdot 1$ & - & - & - \\
\hline 2 & M & T2N1a MO(III) & $7(\mathrm{~A})$ & 35 & 156 & $2 \cdot 3$ & + & + & - \\
\hline 3 & $\mathrm{~F}$ & T2N1a MO(III) & $8(\mathrm{~A})$ & 58 & $459 \cdot 6$ & $2 \cdot 55$ & ++ & - & - \\
\hline 4 & $\mathrm{~F}$ & T3NO MO(II) & $7(\mathrm{~A})$ & 29 & $6 \cdot 33$ & $0 \cdot 6$ & +++ & +++ & - \\
\hline 5 & M & T2NOMO(II) & $9(\mathrm{~A})$ & 38 & ND & $360 \cdot 3$ & +++ & +++ & + \\
\hline 6 & $\mathrm{~F}$ & T2N1M1(IVC) & $7(\mathrm{~A})$ & 53 & ND & ND & +++ & +++ & + \\
\hline 7 & $\mathrm{~F}$ & T2N1b M0(IVA) & $6(\mathrm{~A})$ & 66 & $75 \cdot 1$ & $11 \cdot 3$ & ++ & + & - \\
\hline 8 & M & T4aN1aM1(IVA) & $1(\mathrm{~L})$ & 36 & 1623 & 65 & + & - & - \\
\hline 9 & $\mathrm{~F}$ & T3N1 MO(III) & $2(\mathrm{~L})$ & 55 & 2474 & $2 \cdot 34$ & +++ & +++ & + \\
\hline 10 & $\mathrm{~F}$ & T2NOMO(II) & $4(\mathrm{~A})$ & 69 & ND & ND & ++ & + & - \\
\hline 11 & $M$ & T2NOMO(II) & $1(\mathrm{~L})$ & 63 & ND & $1 \cdot 88$ & +++ & ++++ & - \\
\hline
\end{tabular}

A, alive; L, lost to follow-up; ND, not done. Normal range: calcitonin, male: $<90 \mathrm{pg} / \mathrm{ml}$; female: $<70 \mathrm{pg} / \mathrm{ml}$; CEA, $0-2 \cdot 5 \mathrm{ng} / \mathrm{ml}$. Immunohistochemistry score according to the percentage of positive cells: - , negative;,$+ 5-15 \% ;++, 15-40 \% ;+++, 40-60 \% ;++++,>60 \%$. 
cells were counted in ten different fields $(\times 200)$ and positivity was calculated.

\section{Statistical analysis}

Values are expressed as mean \pm s.D. Data analysis was performed by the Statistics Package for Social Sciences (SPSS system for Windows $12 \cdot 0$, SPSS Inc., Chicago, IL, USA). Differences between groups were analyzed using Student's $t$-test, and $P<0 \cdot 05$ was considered statistically significant.

\section{Results}

\section{Expression of ERs in human MTC tumor}

ER $\alpha$ was detected in 10 out of $11(90 \cdot 9 \%)$ tumors. Five tumor samples exhibited higher (50\% cells positive) levels of ER $\alpha$ expression. ER $\beta$ was absent in three (27.3\%) tumors. Eight tumor samples were positive for ER $\beta$, and five of them exhibited higher ( $>40 \%$ cells positive) levels of ER $\beta$ positivity. The one without $\operatorname{ER} \alpha$ also did not have $\operatorname{ER} \beta$ expression. Five tumors with higher $\mathrm{ER} \alpha$ expression also had higher ER $\beta$ expression, and three of these were also positive for Ki67 positivity. There was no difference in $\operatorname{ER} \alpha$ and $\operatorname{ER} \beta$ expression according to gender, TNM tumor staging, or survival (Table 1). Positivity for ERs or Ki67 was not correlated with serum levels of calcitonin and CEA. We also performed immunohistochemical staining of ERs in normal human thyroid tissue as a control and found ER $\beta$ expression in parafollicular $C$ cells and thyrocytes. ER $\beta$ expression was also detected in parafollicular $C$ cells and thyrocytes surrounding the tumors. However, we did not detect $\mathrm{ER} \alpha$ in normal thyrocytes or parafollicular C cells from either normal thyroid gland or normal thyroid tissues adjacent to the tumors (Fig. 1A).

\section{Expression of ERs in TT cells infected with adenoviral vectors}

First, we examined the presence of ER $\alpha$ or ER $\beta$ in MTC TT cells by immunofluorescence staining and western blot analysis. ERs were not detected in TT cells (data not shown). Secondly, we infected TT cells with Ad-ER $\alpha$ or Ad-ER $\beta$. Ad-E-infected cells served as a negative control. The expression of ER $\alpha$ or ER $\beta$ was detected by immunofluorescence in the nuclei of TT cells infected with Ad-ER $\alpha$ or Ad-ER $\beta$, but not in cells infected with Ad-E (Fig. 2A and $\mathrm{B})$. The ER expression was detected in $85-95 \%$ of TT cells infected with $10 \mathrm{PFU} /$ cell of adenoviral vectors (Fig. 2A and B). Then, further experiments were performed by equivalent amount of adenoviral vectors.

\section{Transcriptional activity of ERs delivered by adenoviral vectors}

We evaluated whether expression of ERs delivered by adenoviral vectors activates an estrogen-responsive reporter gene, by co-infecting Ad-3ERE-Luc into TT cells with

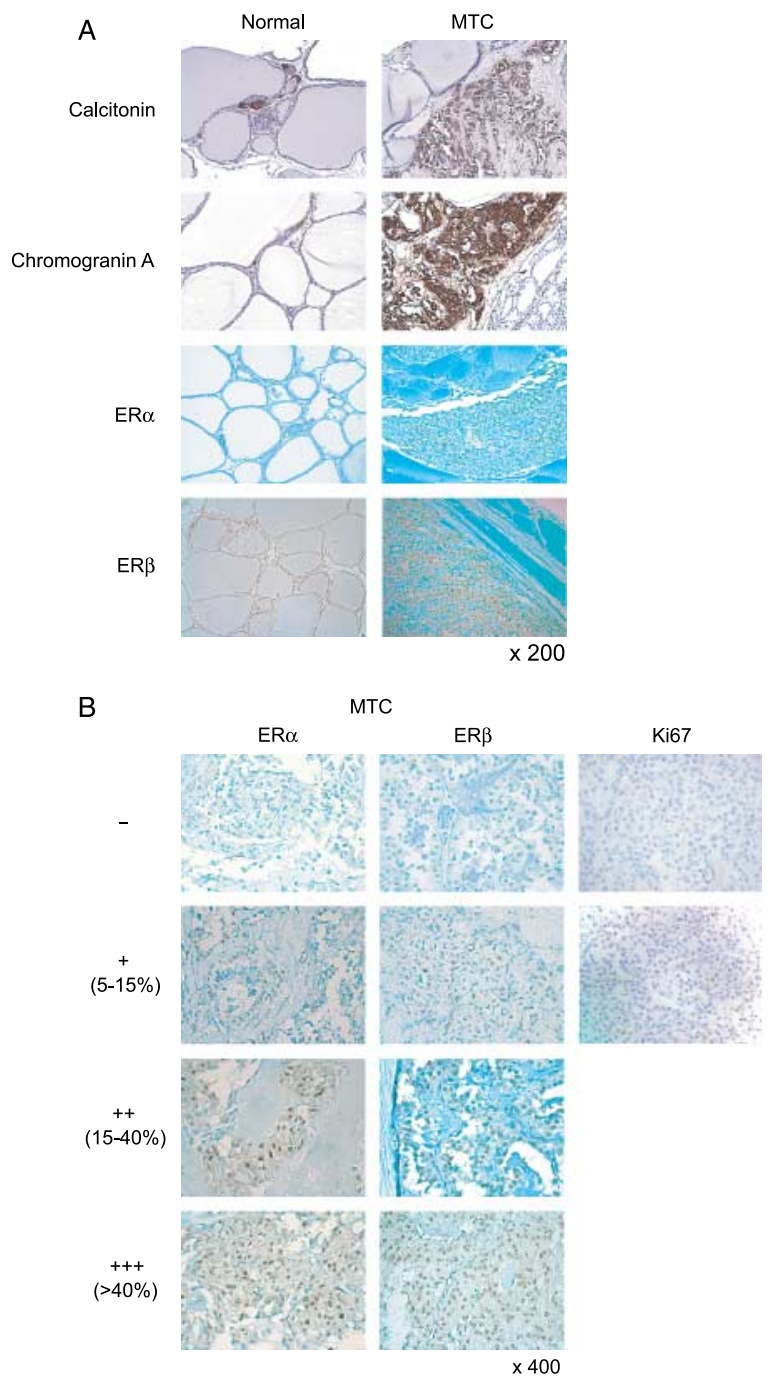

Figure 1 Immunohistochemical staining of normal thyroid and MTC tumor tissues. Four micrometer sections of paraffin-embedded tumors were subjected to immunohistochemistry to detect calcitonin, chromogranin-A, ER $\alpha, E R \beta$, and Ki67 using specific antibodies as described in the Materials and Methods section. Red arrow indicates positivity. (A) Photographs of representative samples $(X$ 200). (B) Immunohistochemical positivity for $E R \alpha, E R \beta$, and Ki67 was scored according to the number of positive cells: -, negative; ,$+ 5-15 \% ;++, 15-40 \% ;+++$,

$40-60 \% ;++++,>60 \%(\times 400)$.

Ad-ER $\alpha$ or Ad-ER $\beta$. As shown in Fig. 3, ERE reporter gene activity was not detected with or without $\mathrm{E}_{2}$ in control Ad-E-infected cells. Infection with Ad-ER $\alpha$ or Ad-ER $\beta$ increased reporter activity without ligand, presumably due to residual estrogen in the medium. $\mathrm{E}_{2}(1 \mathrm{nM})$ addition activated reporter activity by ten- and fivefold in Ad-ER $\alpha$ - and Ad-ER $\beta$-infected cells respectively. ICI 182780 , an antiestrogen treatment, suppressed reporter activities. These results suggested that expression of $\mathrm{ER} \alpha$ or $\mathrm{ER} \beta$ delivered by adenoviral vectors is functionally active in the ERE 
A

Anti-ER $\alpha$

(FITC)

DAPI

B

Anti-ER $\beta$

(Texas-Red)

DAPI
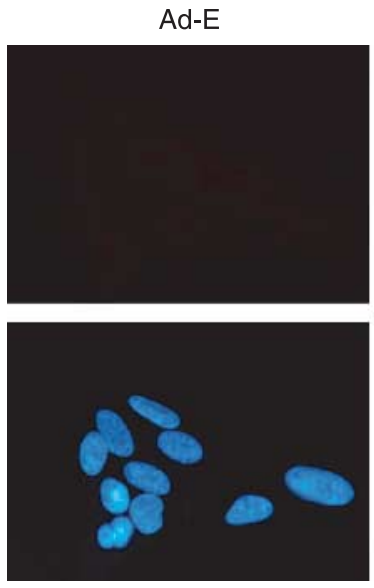

C

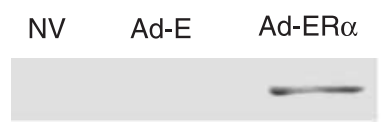

Anti-ER $\alpha$
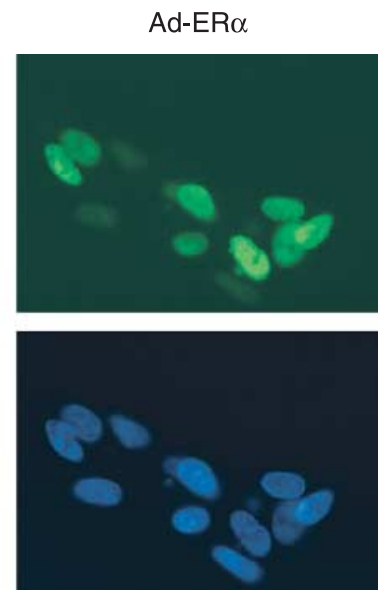

Ad-ER $\beta$
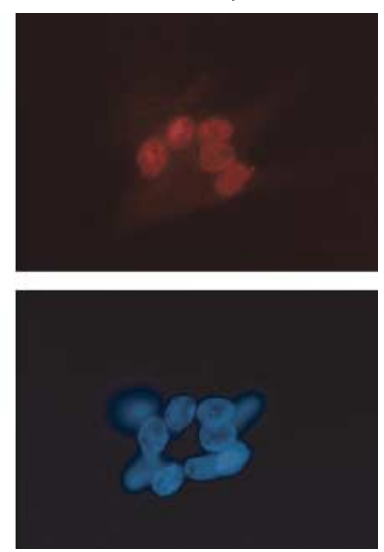

$x 630$

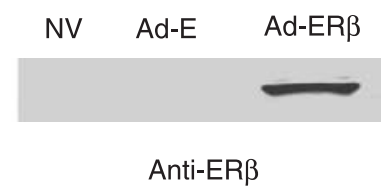

Figure 2 Expression of ER $\alpha$ or ER $\beta$ in TT cells after infection with Ad-ER $\alpha$ or Ad-ER $\beta$. Forty-eight hours after adenoviral infection, immunofluorescence staining ( $A$ and $B$ ) and western blot analysis $(\mathrm{C})$ were performed by mouse monoclonal antibodies as described in the Materials and Methods section $(\times 630)$. NV, no virus.

reporter system and that both ERs act similarly in the classical ERE-mediated pathway in TT cells.

\section{Effect of ER $\alpha$ or ER $\beta$ on TT cell growth}

To investigate whether the introduction of $\mathrm{ER} \alpha$ or $\mathrm{ER} \beta$ in TT cells affects cell growth, we analyzed the proliferation of TT cells infected with two different doses (10 and 20 $\mathrm{PFU} /$ cell) of adenoviral vectors. Ten PFU/cell of Ad-ER $\alpha$ stimulated $\mathrm{TT}$ cell growth without $\mathrm{E}_{2}$ treatment, and the treatment with $\mathrm{E}_{2}(1 \mathrm{nM})$ for 8 days stimulated cell growth further. With a higher dose $(20 \mathrm{PFU} /$ cell) of Ad-ER $\alpha$, growth stimulation was observed in the $E_{2}$ treatment. Ad-ER $\beta$ infection resulted in the suppression of TT cell growth regardless of $E_{2}$ treatment. Growth suppression was more prominent with a higher dose (20 PFU/cell) of Ad-ER $\beta$. ICI 182780 treatment suppressed the growth of TT cell infected with either Ad-ER $\alpha$ or Ad-ER $\beta$, and growth suppression was more prominent in Ad-ER $\beta$ than Ad-ER $\alpha$ infection (Fig. 4). A positive TUNEL reaction was 

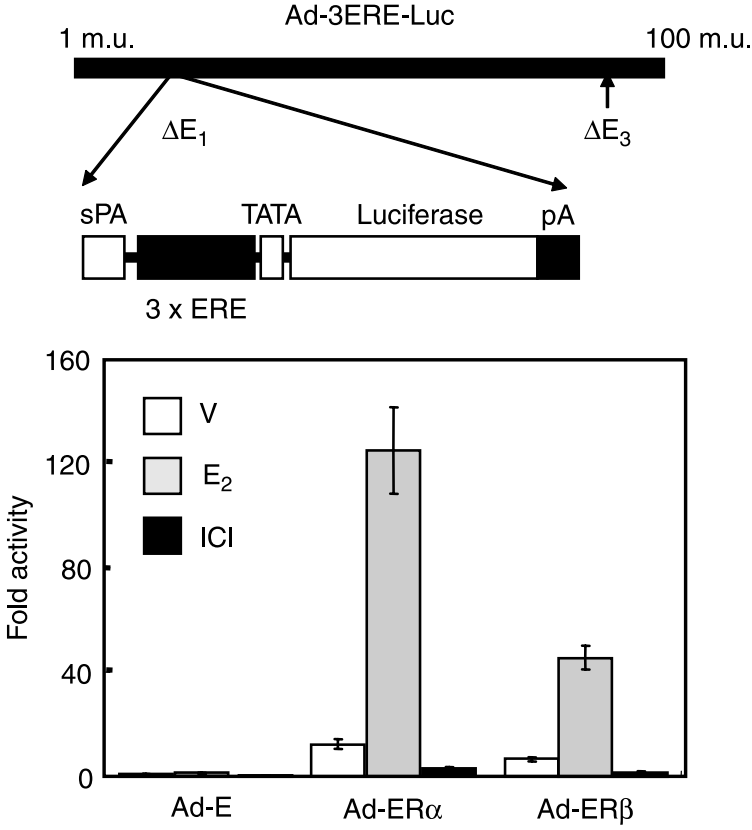

Figure 3 Transcriptional activity of ERs transduced by adenoviral vectors on artificial ERE reporter system. Ad-3ERE-Luc was co-infected into TT cells with Ad-ER $\alpha$ or Ad-ER $\beta$ and Luciferase activity was assayed as described in the Materials and Methods section. Three independent experiments were normalized to the activity of Ad-E-infected TT cells treated with ethanol vehicle. Results are plotted as mean \pm S.D. $\mathrm{V}$, vehicle (ethanol); $\mathrm{E}_{2}, \mathrm{E}_{2}(1 \mathrm{nM}) ; \mathrm{ICl}, \mathrm{ICl} 182780$ (100 nM). obtained in Ad-ER $\beta$ infection (19.8\%), whereas positivity was negligible in Ad-ER $\alpha$-infected $(3 \cdot 2 \%)$ or Ad-E-infected $(<1 \%)$ cells (Fig. 5).

\section{Effect of ERs on AP1 pathway in TT cells}

To investigate the possible mechanisms of different effects of ER $\alpha$ or ER $\beta$ expression on TT cell growth, we evaluated a non-ERE-mediated pathway in TT cells using the AP1 reporter system (Paech et al. 1997). Co-infection of Ad-AP1-Luc into TT cells with Ad-ER $\alpha$ or Ad-ER $\beta$ was performed. As shown in Fig. 6, AP1 reporter gene activity was negligible in control Ad-E-infected cells. Infection with Ad-ER $\alpha$ or Ad-ER $\beta$ increased AP1 reporter activity without ligand. After the addition of $E_{2}$, AP1 activity was decreased in Ad-ER $\alpha$-infected cells, but increased in Ad-ER $\beta$-infected cells. ICI 182780 treatment decreased AP1 activity in both Ad-ER $\alpha$ - or Ad-ER $\beta$-infected cells, but its activity was higher in Ad-ER $\beta$-infected cells than those infected with Ad-ER $\alpha$. These results suggest that non-ERE-mediated signals are distinct in TT cells expressing $\operatorname{ER} \alpha$ or $\operatorname{ER} \beta$ and could also explain the different effects on cellular growth and proliferation.

\section{Discussion}

Previously, ER $\beta$ expression has been reported in normal thyroid parafollicular C cells (Taylor \& Al-Azzawi 2000) and MTC tumor tissues (Blechet et al. 2007). The presence of

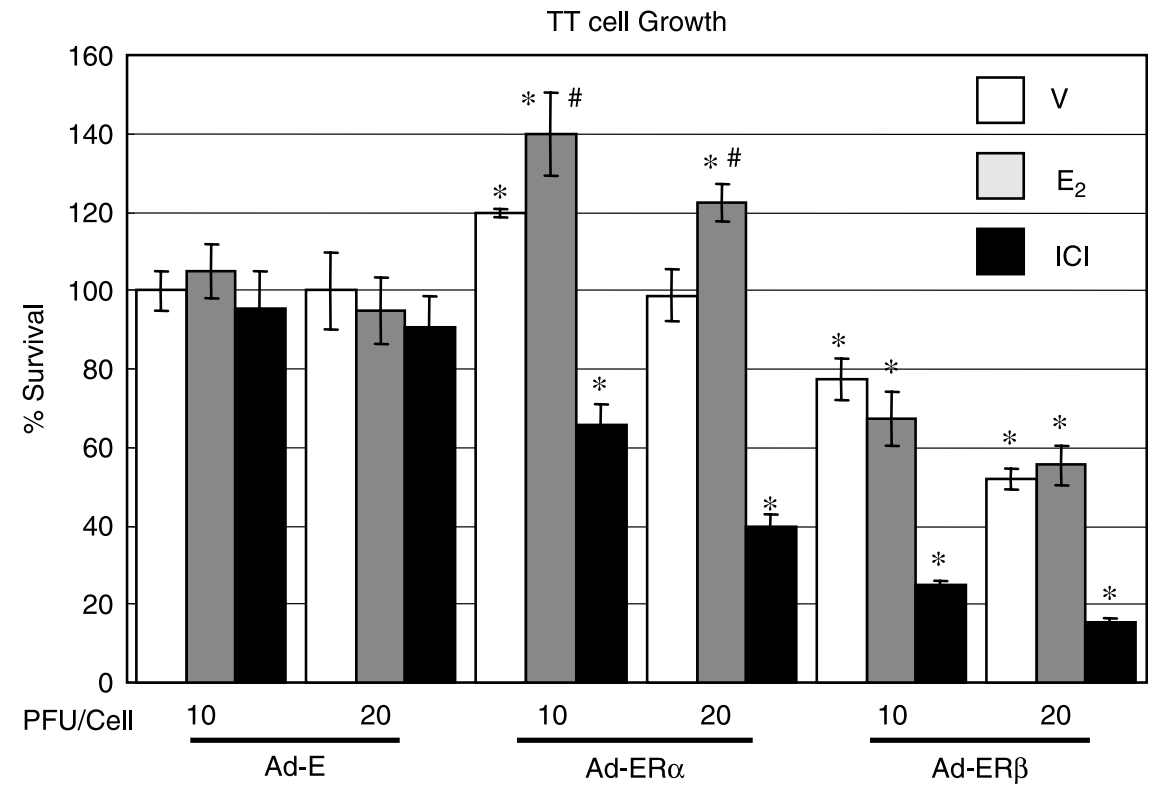

Figure 4 The effect of $E R \alpha$ or ER $\beta$ expression on TT cell growth. Cells were plated, infected, and treated as described in the Materials and Methods section. After treatment for 8 days with $\mathrm{E}_{2}$ or $\mathrm{ICI}$ 182780 , cell growth was determined by cell proliferation assay as described in the Materials and Methods section. All results are plotted as mean \pm s.D. for three independent experiments. Student's $t$-test was performed between values. ${ }^{*} P<0 \cdot 05$ when compared with corresponding condition in $\mathrm{Ad}-\mathrm{E}$ infection and ${ }^{\#} P<0 \cdot 05$ when compared with the condition without $\mathrm{E}_{2}$ treatment in $\mathrm{Ad}-\mathrm{ER} \alpha$ infection. $V$, vehicle (ethanol); $E_{2}, E_{2}(1 \mathrm{nM}) ; \mathrm{ICl}, \mathrm{ICI} 182780$ (100 nM). 


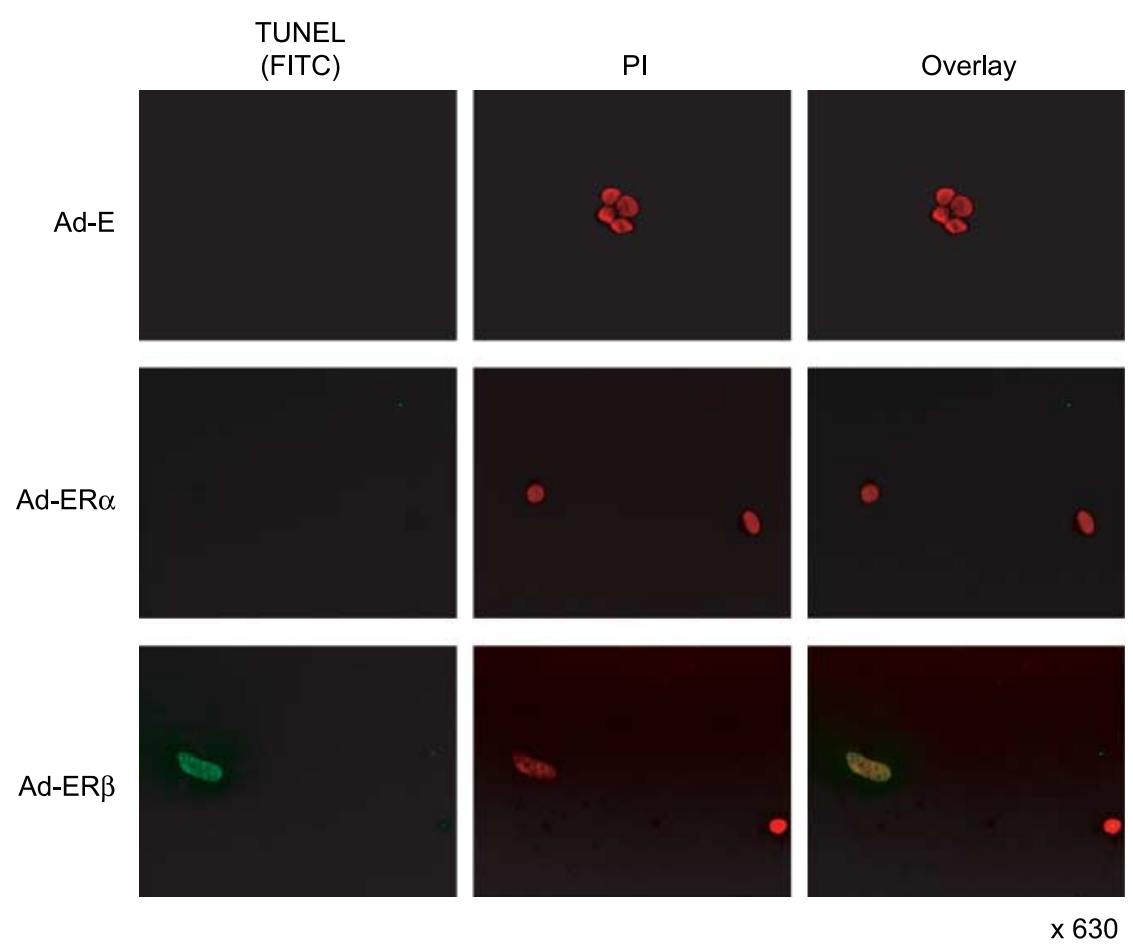

Figure 5 The effect of ER $\alpha$ or ER $\beta$ on TT cell apoptosis. TT cells were infected with adenoviral vectors at an $\mathrm{MOI}$ of $10 \mathrm{PFU} / \mathrm{cell}$. After 6 days of treatment with $\mathrm{E}_{2}(1 \mathrm{nM})$, TUNEL assays were performed. Green fluorescence indicates TUNEL labeling $(\times 630)$.

mRNA for ER $\alpha$ and ER $\beta$ has also been demonstrated in the human MTC tumor tissues (Egawa et al. 2001). However, the role of each ER expression is not well defined after cancerous change. In this study, we have shown an appearance of ER $\alpha$ $(10 / 11)$ and a loss of ER $\beta$ expression (3/11) in the human MTC tissue samples. It has been well demonstrated that expression of ER $\beta$ mRNA and protein decreased or $\mathrm{ER} \alpha / \mathrm{ER} \beta \mathrm{mRNA}$ ratio increased in tumor versus normal tissues in many cancers including breast, ovary, prostate, and colon (Brandenberger et al. 1998, Foley et al. 2000, Rutherford et al. 2000, Campbell-Thompson et al. 2001, Roger et al. 2001, Fixemer et al. 2003, Bardin et al. 2004). Consistent with these reports, appearance of $\mathrm{ER} \alpha$ and loss of ER $\beta$ in MTC tumor tissue in our study may result in the increased ratio of $\mathrm{ER} \alpha / \mathrm{ER} \beta$, suggesting a possible role in tumor growth and progression. Although Ki67, a mitotic index, was detected in both $E R \alpha$ - and $E R \beta$-positive tumors, its expression did not correlate with ER $\alpha$ and $\operatorname{ER} \beta$ expression because these three Ki67-positive tumors had similar levels of both ER $\alpha$ and ER $\beta$. In addition, the expression of ERs did not correlate with cervical lymphadenopathy or distant metastasis (TNM staging), suggesting other signals (Wang et al. 1997, Mustafa et al. 2004), besides ERs, are involved in tumor growth and progression. Of note is that the number of MTC cases in our study was also limited.

The presence of ER $\alpha$ expression could also open the possibility of using anti-estrogenic compounds for the treatment of MTC. In one report, tamoxifen inhibited the growth of medullary carcinoma DR081 cells in an in vitro culture and in vivo tumor cell xenograft implants (Weber et al. 1990). In another report, tamoxifen treatment failed to show clinical or biochemical improvement of two MTC patients (one man and one woman) after 1-3 months of therapy (Garcia-Pascual et al. 1993). The presence of ERs was not identified in either of these reports. It has been suggested that ER $\beta$ is significantly up-regulated in tamoxifen-resistant breast cells and could be involved in tamoxifen resistance (Speirs et al. 1999a,b). Although ER $\beta$ was still detected in most ER $\alpha$-expressing MTC tumor tissues in our study, tamoxifen could be a potential therapeutic agent for the treatment of MTC. The effect of this reagent could be evaluated through therapeutic trial as an adjuvant treatment in both genders (Garcia-Pascual et al. 1993).

To examine the roles of ER $\alpha$ and ER $\beta$ in MTC, we used adenovirus-mediated expression of each ER in MTC TT cells devoid of both endogenous receptors. We observed that both ER $\alpha$ and ER $\beta$ expressed by adenoviral vector were functional in TT cells, resulting in the activation of ERE-mediated gene transcription in a reporter assay. However, we obtained opposing cellular responses with regard to proliferation and apoptosis. ER $\alpha$ acted as a growth stimulator with estrogen addition, whereas ER $\beta$ suppressed cell growth regardless of estrogen treatment in this study. We also investigated whether the different effects of each ER on TT cell growth could be reversed by ICI 182780 , an anti-estrogen, but ICI 182780 

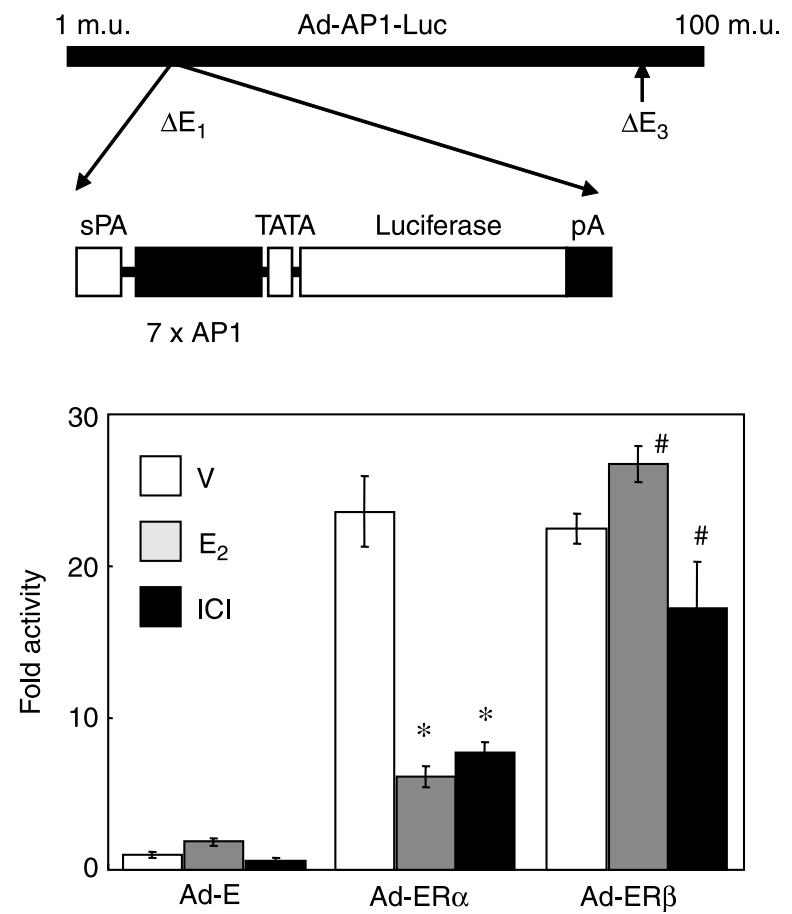

Figure 6 Effect of ERs transduced by adenoviral vectors on an artificial AP1 reporter system. Ad-AP1-Luc was co-infected into TT cells with $\mathrm{Ad}-\mathrm{ER} \alpha$ or $\mathrm{Ad}-\mathrm{ER} \beta$ and Luciferase activity was assayed as described in the Materials and Methods section. Three independent experiments were normalized to the activity of Ad-E-infected TT cells treated with ethanol vehicle. Results are plotted as mean \pm s.D. $* P<0 \cdot 01$ when compared with the condition with vehicle treatment in Ad-ER $\alpha$ infection and ${ }^{\#} P<0.05$ when compared with the condition with vehicle treatment in Ad-ER $\beta$ infection. $V$, vehicle (ethanol); $E_{2}, E_{2}(1 \mathrm{nM}) ; \mathrm{ICl}, \mathrm{ICl} 182780$ (100 nM).

suppressed the growth of TT cells expressing either ER $\alpha$ or ER $\beta$. Growth suppression was more prominent in Ad-ER $\beta$ infected cells. This result suggests the presence of other pathways besides the classical ERE-mediated pathway.

The ER has been known to regulate target genes by at least two major pathways. The classical pathway for ER signaling is mediated by receptor binding to EREs. This mode of ER action has been documented for many genes involved in reproduction as well as genes involved in cellular growth and metabolism (Jakacka et al. 2001, 2002). In addition to this classical pathway of estrogen action, the ER can also alter gene transcription by a mechanism that does not require direct ER binding to an ERE. This non-classical pathway affects gene expression from promoters containing an AP1 site (Paech et al. 1997, Jakacka et al. 2001, O'Brien et al. 2006). We tested this possibility using AP1-Luc, the representative non-ERE-mediated reporter system (Paech et al. 1997). Adenovirus carrying AP1 Luc (AdAP1-luc) was created and co-infected into TT cells with Ad-ER $\alpha$ or Ad-ER $\beta$. The effect of estrogen and anti-estrogen on AP1-reporter in TT cells was distinct according to ER $\alpha$ or ER $\beta$ expression. Estrogen and anti-estrogen treatment suppressed AP1 activity in Ad-ER $\alpha$-infected cells, whereas alongside Ad-ER $\beta$ infection, estrogen further stimulated AP1 activity which in turn is suppressed by anti-estrogen. Suppressed AP1 activity by ICI 182780 was still higher in ER $\beta$ than ER $\alpha$ expression. This result indicates that signals other than the classical ERE-mediated pathway might regulate genes including apoptotic factors and negative cell cycle regulators. Genes responsible for regulating the different actions by $\mathrm{ER} \alpha$ or $\mathrm{ER} \beta$ still remain to be determined in these TT cell models.

A series of studies revealed that the ER $\beta$ presence confers a more favorable prognosis and is also associated with low-grade tumors, low S-phase fraction, negative axillary node status, and a higher disease-free survival rate (Jarvinen et al. 2000, Omoto et al. 2001). In addition, exogenously expressing ER $\beta$ not only inhibits proliferation and invasion but also induces apoptosis in many cancer cells (Lazennec et al. 2001, Qiu et al. 2002, Cheng et al. 2004, Paruthiyil et al. 2004). Repression of c-myc, cyclin D1, and cyclin A gene transcription and increasing the expression of p21Cip1 and p27Kip1 were demonstrated by ER $\beta$ expression (Paruthiyil et al. 2004). These result in a G2 cell cycle arrest. The activation of caspase-3 has also been demonstrated in ER-negative prostate cancer cells, in which ER $\beta$ was reintroduced by adenoviral vector (Cheng et al. 2004). Although we did not find an association between ER $\beta$ expression and tumor behavior in human MTC tumor samples, an anti-tumor effect of ER $\beta$ expression was observed in the TT cell line. These results indicate a potential anti-neoplastic role of ER $\beta$, which is in good agreement with previous studies (Lazennec et al. 2001, Qiu et al. 2002, Cheng et al. 2004, Paruthiyil et al. 2004), and also suggest different roles of ER $\alpha$ and ER $\beta$ in MTC tumor growth. New therapeutic approaches for MTC might include pharmaceutical agents to block ER activity and gene therapy by delivery of ER $\beta$.

\section{Acknowledgements}

We thank Su-Il Ji for tissue preparation. This work was supported by the Internal Medicine Research Grant 20062007 from the Yonsei University College of Medicine and a New Faculty Grant (2007) from the Yonsei University. The authors declare that there is no conflict of interest that would prejudice the impartiality of this scientific work.

\section{References}

Arain SA, Shah MH, Meo SA \& Jamal Q 2003 Estrogen receptors in human thyroid gland. An immunohistochemical study. Saudi Medical Journal 24 174-178.

Bardin A, Boulle N, Lazennec G, Vignon F \& Pujol P 2004 Loss of ERbeta expression as a common step in estrogen-dependent tumor progression. Endocrine-Related Cancer 11 537-551.

Blechet C, Lecomte P, De Calan L, Beutter P \& Guyetant S 2007 Expression of sex steroid hormone receptors in $\mathrm{C}$ cell hyperplasia and medullary thyroid carcinoma. Virchows Archiv 450 433-439.

Brandenberger AW, Tee MK \& Jaffe RB 1998 Estrogen receptor alpha (ER-alpha) and beta (ER-beta) mRNAs in normal ovary, ovarian serous cystadenocarcinoma and ovarian cancer cell lines: down-regulation of ER-beta in neoplastic tissues. Journal of Clinical Endocrinology and Metabolism 83 1025-1028.

Bur M, Shiraki W \& Masood S 1993 Estrogen and progesterone receptor detection in neoplastic and non-neoplastic thyroid tissues. Modern Pathology 6 469-472. 
Cady B, Sedgwick CE, Meissner WA, Wool MS, Salzman FA \& Werber J 1979 Risk factor analysis in differentiated thyroid cancer. Cancer $\mathbf{4 3}$ 810-820.

Campbell-Thompson M, Lynch IJ \& Bhardwaj B 2001 Expression of estrogen receptor (ER) subtypes and ERbeta isoforms in colon cancer. Cancer Research 61 632-640.

Cheng J, Lee EJ, Madison LD \& Lazennec G 2004 Expression of estrogen receptor beta in prostate carcinoma cells inhibits invasion and proliferation and triggers apoptosis. FEBS Letters 566 169-172.

Colomer A, Martinez-Mas JV, Matias-Guiu X, Llorens A, Cabezas R, Prat J \& Garcia-Ameijeiras A 1996 Sex-steroid hormone receptors in human medullary thyroid carcinoma. Modern Pathology 9 68-72.

Egawa C, Miyoshi Y, Iwao K, Shiba E \& Noguchi S 2001 Quantitative analysis of estrogen receptor-alpha and -beta messenger RNA expression in normal and malignant thyroid tissues by real-time polymerase chain reaction. Oncology 61 293-298.

Fixemer T, Remberger K \& Bonkhoff H 2003 Differential expression of the estrogen receptor beta (ERbeta) in human prostate tissue, premalignant changes, and in primary, metastatic, and recurrent prostatic adenocarcinoma. Prostate $\mathbf{5 4}$ 79-87.

Foley EF, Jazaeri AA, Shupnik MA, Jazaeri O \& Rice LW 2000 Selective loss of estrogen receptor beta in malignant human colon. Cancer Research 60 245-248.

Garcia-Pascual L, Millan M, Anglada J \& Garau J 1993 Tamoxifen failure in medullary thyroid carcinoma. Tumori 79 357-358.

Hiasa Y, Nishioka H, Kitahori Y, Yane K, Nakaoka S, Ohshima M, Konishi N, Nishii K, Kitamura M \& Matsunaga T 1993 Immunohistochemical analysis of estrogen receptors in 313 paraffin section cases of human thyroid tissue. Oncology 50 132-136.

Jakacka M, Ito M, Weiss J, Chien PY, Gehm BD \& Jameson JL 2001 Estrogen receptor binding to DNA is not required for its activity through the nonclassical AP1 pathway. Journal of Biological Chemistry 276 13615-13621.

Jakacka M, Ito M, Martinson F, Ishikawa T, Lee EJ \& Jameson JL 2002 An estrogen receptor (ER)alpha deoxyribonucleic acid-binding domain knock-in mutation provides evidence for nonclassical ER pathway signaling in vivo. Molecular Endocrinolgy 16 2188-2201.

Jarvinen TA, Pelto-Huikko M, Holli K \& Isola J 2000 Estrogen receptor beta is coexpressed with ERalpha and PR and associated with nodal status, grade, and proliferation rate in breast cancer. American Journal of Pathology 156 29-35.

Kebebew E, Ituarte PH, Siperstein AE, Duh QY \& Clark OH 2000a Medullary thyroid carcinoma: clinical characteristics, treatment, prognostic factors, and a comparison of staging systems. Cancer 88 1139-1148.

Kebebew E, Kikuchi S, Duh QY \& Clark OH $2000 b$ Long-term results of reoperation and localizing studies in patients with persistent or recurrent medullary thyroid cancer. Archives of Surgery 135 895-901.

Latil A, Bieche I, Vidaud D, Lidereau R, Berthon P, Cussenot O \& Vidaud M 2001 Evaluation of androgen, estrogen (ER alpha and ER beta), and progesterone receptor expression in human prostate cancer by real-time quantitative reverse transcription-polymerase chain reaction assays. Cancer Research 61 1919-1926.

Lazennec G, Bresson D, Lucas A, Chauveau C \& Vignon F 2001 ER beta inhibits proliferation and invasion of breast cancer cells. Endocrinology 142 4120-4130.

Leav I, Lau KM, Adams JY, McNeal JE, Taplin ME, Wang J, Singh H \& Ho SM 2001 Comparative studies of the estrogen receptors beta and alpha and the androgen receptor in normal human prostate glands, dysplasia, and in primary and metastatic carcinoma. American Journal of Pathology 159 79-92.

Lee C, Kao H, Lin H, P'Eng F \& Chi C 1998 Estrogen receptors and glucocorticoid receptors in human well-differentiated thyroid cancer. International Journal of Molecular Medicine 2 229-233.

Lee EJ, Jakacka M, Duan WR, Chien PY, Martinson F, Gehm BD \& Jameson JL 2001 Adenovirus-directed expression of dominant negative estrogen receptor induces apoptosis in breast cancer cells and regression of tumors in nude mice. Molecular Medicine 7 773-782.

Lewy-Trenda I 2002 Estrogen and progesterone receptors in neoplastic and non-neoplastic thyroid lesions. Polish Journal of Pathology 53 67-72.

Marsh DJ, Learoyd DL \& Robinson BG 1995 Medullary thyroid carcinoma: recent advances and management update. Thyroid $\mathbf{5} 407-424$.
Messina M, Yu DM, Learoyd DL, Both GW, Molloy PL \& Robinson BG 2000 High level, tissue-specific expression of a modified calcitonin/ calcitonin gene-related peptide promoter in a human medullary thyroid carcinoma cell line. Molecular and Cellular Endocrinology 164 219-224.

Mustafa T, Klonisch T, Hombach-Klonisch S, Kehlen A, Schmutzler C, Koehrle J, Gimm O, Dralle H \& Hoang-Vu C 2004 Expression of CD97 and CD55 in human medullary thyroid carcinomas. International Journal of Oncology 24 285-294.

Naveh-Many T, Almogi G, Livni N \& Silver J 1992 Estrogen receptors and biologic response in rat parathyroid tissue and C cells. Journal of Clinical Investigations 90 2434-2438.

O'Brien JE, Peterson TJ, Tong MH, Lee EJ, Pfaff LE, Hewitt SC, Korach KS, Weiss J \& Jameson JL 2006 Estrogen-induced proliferation of uterine epithelial cells is independent of estrogen receptor alpha binding to classical estrogen response elements. Journal of Biological Chemistry $28126683-26692$.

Omoto Y, Inoue S, Ogawa S, Toyama T, Yamashita H, Muramatsu M, Kobayashi S \& Iwase H 2001 Clinical value of the wild-type estrogen receptor beta expression in breast cancer. Cancer Letters 163 207-212.

Paech K, Webb P, Kuiper GG, Nilsson S, Gustafsson J, Kushner PJ \& Scanlan TS 1997 Differential ligand activation of estrogen receptors ERalpha and ERbeta at AP1 sites. Science 277 1508-1510.

Paruthiyil S, Parmar H, Kerekatte V, Cunha GR, Firestone GL \& Leitman DC 2004 Estrogen receptor beta inhibits human breast cancer cell proliferation and tumor formation by causing a G2 cell cycle arrest. Cancer Research 64 423-428.

Petrangolini G, Cuccuru G, Lanzi C, Tortoreto M, Belluco S, Pratesi G, Cassinelli G \& Zunino F 2006 Apoptotic cell death induction and angiogenesis inhibition in large established medullary thyroid carcinoma xenografts by Ret inhibitor RPI-1. Biochemical Pharmacology 72 405-414.

Pujol P, Rey JM, Nirde P, Roger P, Gastaldi M, Laffargue F, Rochefort H \& Maudelonde T 1998 Differential expression of estrogen receptor-alpha and -beta messenger RNAs as a potential marker of ovarian carcinogenesis. Cancer Research 58 5367-5373.

Qiu Y, Waters CE, Lewis AE, Langman MJ \& Eggo MC 2002 Oestrogeninduced apoptosis in colonocytes expressing oestrogen receptor beta. Journal of Endocrinology 174 369-377.

Roger P, Sahla ME, Makela S, Gustafsson JA, Baldet P \& Rochefort H 2001 Decreased expression of estrogen receptor beta protein in proliferative preinvasive mammary tumors. Cancer Research 61 2537-2541.

Rutherford T, Brown WD, Sapi E, Aschkenazi S, Munoz A \& Mor G 2000 Absence of estrogen receptor-beta expression in metastatic ovarian cancer. Obstetrics and Gynecology 96 417-421.

Speirs V, Malone C, Walton DS, Kerin MJ \& Atkin SL 1999a Increased expression of estrogen receptor beta mRNA in tamoxifen-resistant breast cancer patients. Cancer Research 59 5421-5424.

Speirs V, Parkes AT, Kerin MJ, Walton DS, Carleton PJ, Fox JN \& Atkin SL $1999 b$ Coexpression of estrogen receptor alpha and beta: poor prognostic factors in human breast cancer? Cancer Research 59 525-528.

Taylor AH \& Al-Azzawi F 2000 Immunolocalisation of oestrogen receptor beta in human tissues. Journal of Molecular Endocrinology 24 145-155.

Wang W, Johansson HE, Bergholm UI, Westermark KM \& Grimelius LE 1997 Expression of c-Myc, TGF-alpha and EGF-receptor in sporadic medullary thyroid carcinoma. Acta Oncologica 36 407-411.

Weber CJ, Marvin M, Krekun S, Koschitzky T, Karp F, Benson M \& Feind CR 1990 Effects of tamoxifen and somatostatin analogue on growth of human medullary, follicular, and papillary thyroid carcinoma cell lines: tissue culture and nude mouse xenograft studies. Surgery 108 1065-1071.

Yane K, Tanaka O, Miyahara H, Matsunaga T, Kitahori Y \& Hiasa Y 1993 Immunohistochemical study of epidermal growth factor receptor and estrogen receptor in human thyroid tumors. Nippon Jibiinkoka Gakkai Kaiho 96 787-790.

Yane K, Kitahori Y, Konishi N, Okaichi K, Ohnishi T, Miyahara H, Matsunaga T, Lin JC \& Hiasa Y 1994 Expression of the estrogen receptor in human thyroid neoplasms. Cancer Letters 84 59-66.

\section{Received in final form 19 August 2007}

Accepted 30 August 2007

Made available online as an Accepted Preprint 30 August 2007 